\title{
Sexually Transmitted Diseases: from HPV to HTLV - clinical profile and associated factors
}

\author{
Fabíola Suris da Silveira ${ }^{1,2}$
}

Renan Rangel Bonamigo ${ }^{1,3}$

DOI: http:/ /dx.doi.org/10.1590/abd1806-4841.20153663

\begin{abstract}
The Brazilian Ministry of Health recommends the performance of serological tests in patients with clinical signs of Sexually Transmitted Diseases. However, data are lacking to affirm the necessity of testing these patients for human T-lymphotropic virus type 1 or type 2 . This is a cross-sectional study with 120 patients seen at the Sexually Transmitted Diseases unit of the Sanitary Dermatology Outpatient Clinic of Rio Grande do Sul. The serum from none of the patients was positive for human T-lymphotropic virus type 1 or type 2 . Viral warts were the most frequent diagnosis. Drug use was confirmed as a risk factor and high educational levels were found to be a protective factor against Sexually Transmitted Diseases.
\end{abstract}

Keywords: Sexually Transmitted Diseases; Risk Factors; Human T-lymphotropic virus type I; Human T-lymphotropic virus type II

According to the recommended by the Ministry of Health of Brazil, when people with clinical signs of Sexually Transmitted Diseases (STDs) seek health services, they are tested for human immunodeficiency virus (HIV), syphilis, hepatitis B virus and hepatitis C virus. However, according to the local epidemiological context, there is not enough data to affirm the need of testing for human T-lymphotropic virus type I and II (HTLV-1 and -2).
The serologic diagnosis of HTLV-1 and -2 infections could make the identification of new cases of subclinical infection possible and potentially aid in the management of possible clinical manifestations that are attributable to virus. Moreover, it could serve as a warning sign regarding the importance of STD and HTLV coinfection. ${ }^{1}$ This study aimed to: evaluate the relevance of performing a diagnostic screening using a high sensitivity assay for detecting HTLV infection in patients with STDs; and present the clinical and epidemiological profile of a sample of patients with STDs.

Received on 28.04.2014

Approved by the Advisory Board and accepted for publication on 19.09.2014

Study conducted at the Ambulatório de Dermatologia Sanitária do Estado do Rio Grande do Sul e Pós-Graduação em Patologia da Universidade Federal de Ciências da Saúde de Porto Alegre (UFCSPA) - Porto Alegre (RS), Brazil.

Financial Support: None.

Conflict of Interest: None.

Universidade Federal de Ciências da Saúde de Porto Alegre (UFCSPA) - Porto Alegre (RS), Brazil.

Hospital Nossa Senhora da Conceição - Porto Alegre (RS), Brazil.

Ambulatório de Dermatologia Sanitária da Secretaria de Saúde do Estado do Rio Grande do Sul - Porto Alegre (RS), Brazil.

(C2015 by Anais Brasileiros de Dermatologia 
This is a contemporary cross-sectional study with control. We evaluated patients covered by the Unified Health System and seen at the STD unit of Sanitary Dermatology Outpatient Clinic of the State of Rio Grande do Sul.

This study was approved by the Research Ethics Committee of the Federal University of Halth Sciences of Porto Alegre and all patients signed an informed consent form. We used convenience sampling. Categorical data were analyzed using the chi-square test (with or without Yates' correction) or Fisher's exact test. Comparing the groups, the unadjusted odds ratios (ORs) with $95 \%$ confidence intervals $(95 \% \mathrm{CI})$ were calculated by measuring the association between the variables of interest. Logistic regression was performed to adjust the estimates of the potentially associated factors. A value of $p<0.05$ was considered statistically significant, with $80 \%$ power.

Inclusion criteria were: patients with clinical symptoms of sexually transmitted infections, classified according to the syndromic approach into genital ulcers, urethral discharge, vaginal discharge, pelvic pain and genital warts. All patients were tested for HTLV-1 and -2 using the ELISA test (EnzymeLinkedImmunoSorbentAssay). A control group was formed in order to benchmark the results of the HTLV serology (blood donors of the blood bank of the Hospital Santa Casa de Porto Alegre). This happened at the same period as data collection, in August 2011 and April 2012.

The variables studied were age, gender, educational level, city of residence, syndromic diagnosis of STDs, serology for HTLV-1 and -2, serology for syphilis, use of drugs and/or alcohol, history of STD/HIV, history of previous serological tests for STDs, condom use, having a steady sexual partner or multiple sexual partners, and partner's history of STD. Tables 1 and 2 show the main study data.

120 patients were included in the study. 56.7\% were male. The mean age was $30.9( \pm 13.3)$ years. The serum from none of the patients was positive for HTLV-1 and -2 . 10\% of patients had positive serology for syphilis. A higher level of education of eight years and more was associated with an increased use of condoms, when compared with lower levels of education $(p<0.05)$. Drug use was associated with positive serology for HIV, genital ulcers and urethral discharge $(\mathrm{p}<0.05)$.

Genital warts were the most frequently diagnosed STD (48.3\%), revealing the importance of infections caused by papilloma virus (HPV).

The mean seroprevalence of HTLV-1 and -2 in Brazil is $0.5 \%$, with higher prevalence in the North and Northeast and lower prevalence in the South of the country. ${ }^{2,3}$ In Porto Alegre, the prevalence among blood donors is $0.17 \% .^{2}$ On the other hand, the seroprevalence of syphilis $(10 \%)$ was very high, when compared with blood donors used as controls $(0.5 \%)$.

We found a high consumption of licit and illicit drugs (over 75\%) among the participants. There was a significant association between all STDs and the use of at least one type of drug.

A study conducted with adolescents in Ceará demonstrated the influence of alcohol on risk behavior STDs. ${ }^{4,5}$ In our study, the use of drugs was associated with multiple sexual partners and with urethral discharge.

TABLE 1: Frequency distribution of the variables according to the syndromic approach to STD diagnosis

\begin{tabular}{|c|c|c|c|c|c|c|c|}
\hline & & $\begin{array}{l}\text { Genital ulcer } \\
n=27\end{array}$ & $\begin{array}{l}\text { Discharges* } \\
n=33\end{array}$ & $\begin{array}{l}\text { Genital warts } \\
n=58\end{array}$ & $\begin{array}{l}\text { Pelvic Pain } \\
n=3\end{array}$ & Total & $\mathrm{p}$ \\
\hline \multirow[t]{2}{*}{ History of HIV } & Yes & 6 & 3 & 5 & 0 & 14 & $0.253 \S$ \\
\hline & No & 21 & 30 & 53 & 3 & 107 & \\
\hline \multirow[t]{2}{*}{ Drugs use } & Yes & 15 & 25 & 48 & 3 & 91 & $0.039 \S$ \\
\hline & No & 12 & 8 & 10 & 0 & 30 & \\
\hline \multirow[t]{3}{*}{ Condoms use } & Always & 10 & 10 & 19 & 0 & 39 & $0.282 \S$ \\
\hline & Sometimes & 12 & 18 & 32 & 1 & 63 & \\
\hline & Never & 5 & 5 & 7 & 2 & 19 & \\
\hline \multirow{2}{*}{ Steady partner } & Yes & 18 & 18 & 36 & 1 & 73 & $0.593 \S$ \\
\hline & No & 9 & 15 & 22 & 2 & 48 & \\
\hline \multirow[t]{2}{*}{ Multiple partners } & Yes & 8 & 13 & 16 & 1 & 38 & $0.702 \S$ \\
\hline & No & 19 & 20 & 42 & 2 & 83 & \\
\hline \multirow{3}{*}{ Partner with STD } & Yes & 5 & 9 & 10 & 0 & 24 & $0.433 \S$ \\
\hline & No & 12 & 11 & 33 & 2 & 58 & \\
\hline & Does not know & 10 & 13 & 15 & 1 & 39 & \\
\hline
\end{tabular}

* the sum of the urethral and vaginal discharges. §: Pearson's chi-square test 
TABLE 2: Clinical and socio-demographic profile of patients with STD (patients treated at the Sanitary Dermatology Outpatient Clinic of the State of Rio Grande do Sul, 2011 and 2012)

$\mathrm{n}=120$

Mean age $30.9( \pm 13.3)$

Minimum age $=14$ years

Maximum age $=77$ years

\begin{tabular}{|c|c|c|c|c|c|}
\hline & $\mathbf{N}$ & $\%$ & & $\mathbf{N}$ & $\%$ \\
\hline Gender & & & Use Marijuana & & \\
\hline Male & 68 & $56.7 \%$ & Yes & 11 & $9.2 \%$ \\
\hline Female & 52 & $43.3 \%$ & No & 109 & $90.8 \%$ \\
\hline Educational level & & & Use cocaine & & \\
\hline None & 2 & $1.7 \%$ & Yes & 3 & $2.5 \%$ \\
\hline 1-3 years & 7 & $5.8 \%$ & No & 117 & $97.5 \%$ \\
\hline $4-7$ years & 25 & $20.8 \%$ & & & \\
\hline $8-11$ years & 71 & $59.2 \%$ & Use crack & & \\
\hline Incomplete higher education & 11 & $9.2 \%$ & Yes & 1 & $0.8 \%$ \\
\hline Complete higher education & 4 & $3.3 \%$ & No & 119 & $99.2 \%$ \\
\hline City of residence & & & Ingest alcohol & & \\
\hline Porto Alegre, RS, Brazil. & 98 & $81.7 \%$ & Daily & 3 & $2.5 \%$ \\
\hline \multirow[t]{2}{*}{ Others } & 22 & $18.3 \%$ & Sometimes & 78 & $65 \%$ \\
\hline & & & Never & 39 & $32 \%$ \\
\hline \multicolumn{6}{|l|}{ SEROLOGY } \\
\hline Current serology for HTLV & & & OTHER FACTORS & & \\
\hline Negative & 119 & $99.2 \%$ & Use condom & & \\
\hline \multirow[t]{2}{*}{ Inconclusive } & 1 & $0.8 \%$ & Always & 40 & $33.3 \%$ \\
\hline & & & Sometimes & 62 & $51.7 \%$ \\
\hline Serology for Syphilis & & & Never & 18 & $15 \%$ \\
\hline Positive & 12 & $10 \%$ & & & \\
\hline \multirow[t]{2}{*}{ Negative } & 108 & $90 \%$ & History of HIV & & \\
\hline & & & Yes & 14 & $11.7 \%$ \\
\hline SYNDROMIC APPROACH STDs & & & No & 106 & $88.3 \%$ \\
\hline \multicolumn{6}{|l|}{ Vaginal discharge } \\
\hline Yes & 19 & $15.8 \%$ & History of previous STD & & \\
\hline \multirow[t]{2}{*}{ No } & 101 & $84.2 \%$ & Yes & 40 & $33.3 \%$ \\
\hline & & & No & 80 & $66.7 \%$ \\
\hline \multicolumn{6}{|l|}{ Genital ulcer } \\
\hline Yes & 27 & $22.5 \%$ & Were already tested for STD & & \\
\hline \multirow[t]{2}{*}{ No } & 93 & $77.5 \%$ & Yes & 77 & $64.2 \%$ \\
\hline & & & No & 43 & $35.8 \%$ \\
\hline \multicolumn{6}{|l|}{ Pelvic Pain } \\
\hline Yes & 3 & $2.5 \%$ & Have a steady partner & & \\
\hline \multirow[t]{2}{*}{ No } & 117 & $97.5 \%$ & Yes & 73 & $60.8 \%$ \\
\hline & & & No & 47 & $39.2 \%$ \\
\hline \multicolumn{6}{|l|}{ Urethral discharge } \\
\hline Yes & 14 & $11.7 \%$ & Have multiple partners & & \\
\hline \multirow[t]{2}{*}{ No } & 106 & $88.3 \%$ & Yes & 36 & $30 \%$ \\
\hline & & & No & 84 & $70 \%$ \\
\hline \multicolumn{6}{|l|}{ Genital warts } \\
\hline Yes & 58 & $48.3 \%$ & Partner with STD & & \\
\hline \multirow[t]{2}{*}{ No } & 62 & $51.7 \%$ & No & 57 & $47.5 \%$ \\
\hline & & & HIV & 6 & $5.0 \%$ \\
\hline DRUGS AND ALCOHOL USE & & & HTLV & 1 & $0.8 \%$ \\
\hline Smoke cigarettes & & & HPV & 11 & $9.2 \%$ \\
\hline Yes & 40 & $33.3 \%$ & Other & 8 & $6.7 \%$ \\
\hline No & 80 & $66.7 \%$ & Does not know & 37 & $30.8 \%$ \\
\hline
\end{tabular}


High levels of HTLV infection relate to the use of drugs and to relationships with drug users. ${ }^{6,7}$ A study conducted in 2005 showed that $2.4 \%$ of HIV patients were seropositive for HTLV. The use of intravenous cocaine was the most important risk factor. ${ }^{7}$

It is known that low educational levels are associated with a higher prevalence of HTLV-1 and syphilis. ${ }^{89}$ In this study, most participants had an educational level of eight years study or more, and this was associated with the frequent use of condoms. Genital warts were more prevalent in individuals with higher educational levels. This finding may be related to greater concern about health and an increased demand for health care.

\section{REFERENCES}

1. Bittencourt AL, de Oliveira Mde F. Cutaneous manifestations associated with HTLV-1 infection. Int J Dermatol. 2010;49:1099-110.

2. Catalan-Soares B, Carneiro-Proietti AB, Proietti FA; Interdisciplinary HTLV Research Group. Heterogeneous geographic distribution of human T-cell Iymphotropic viruses I and II (HTLV-I/II): serological screening prevalence rates in blood donors from large urban areas in Brazil. Cad Saude Publica. 2005;21:926-31.

3. Romanelli LC, Caramelli P, Proietti AB. Human T cell lymphotropic virus (HTLV-1): when to suspect infection? Rev Assoc Med Bras. 2010;56:340-7.

4. Sampaio Filho FJL, Sousa PRMd, Vieira NFC, Nóbrega MdFB, Gubert FdA, Pinheiro PNdC. Percepção de risco de adolescentes escolares na relação consumo de Álcool e comportamento sexual. Rev Gaúcha Enferm. 2010;31:508-14.

5. Silva $\mathrm{CM}$, Vargens $\mathrm{OMdC}$. A percepção de mulheres quanto à vulnerabilidade feminina para contrair DST/HIV. Rev Esc Enferm USP. 2009;43:401-6.

6. Milagres FA, Duarte MI, Viso AT, Segurado AC. Hepatitis C virus and human T-lymphotropic virus coinfection: epidemiological, clinical, laboratory and histopathological features. Rev Soc Bras Med Trop. 2009;42:363-8.

7. Barcellos NT, Fuchs SC, Mondini LG, Murphy EL. Human T Iymphotropic virus type 1/II infection: prevalence and risk factors in individuals testing for HIV in counseling centers from Southern Brazil. Sex Transm Dis. 2006;33:302-6.

8. Rafatpanah H, Hedayati-Moghaddam MR, Fathimoghadam F, Bidkhori HR, Shamsian SK, Ahmadi S, et al. High prevalence of HTLV-I infection in Mashhad, Northeast Iran: a population-based seroepidemiology survey. J Clin Virol. 2011;52:172-6.

9. Dal Fabbro MM, Cunha RV, Bóia MN, Portela P, Botelho CA, Freitas GM, et al. HTLV 1/2 infection: prenatal performance as a disease control strategy in State of Mato Grosso do Sul. Rev Soc Bras Med Trop. 2008;41:148-51.
In conclusion, viral warts were the most frequently syndromically diagnosed STD and no coinfections with HTLV were observed. The inclusion of a diagnostic screening for detecting HTLV-1 and -2 in patients with STDs does not seem to be relevant for patients seen in a referral center in Porto Alegre. It is noteworthy that the use of drugs constitutes a major risk factor for STDs and the high educational levels are possibly a protective factor against STDs. $\square$
MAILING ADDRESS:
Fabiola Suris da Silveira
Av Joao Pessoa, 1327
Farroupilha
90040001 - Porto Alegre-RS
Brazil.
E-mail: fabisuris@hotmail.com

How cite this article: Silveira FS, Bonamigo RR. Sexually Transmitted Diseases: from HPV to HTLV - clinical profile and factors associated. An Bras Dermatol. 2015; 90(6):915-8. 